\title{
Hybrid Electric Vehicles: A mini Overview
}

\author{
I.H. Shanono ${ }^{1,3^{*}}$ A. Muhammad2,4 \\ ${ }^{1}$ Faculty of Electrical and Electronics Engineering Technology, Universiti Malaysia Pahang, 26600 Pahang, Malaysia. \\ ${ }^{2}$ Faculty of Mechatronics and Manufacturing Engineering Technology, Universiti Malaysia Pahang, 26600 Pahang, Malaysia. \\ ${ }^{3}$ Department of Electrical Engineering, Faculty of Engineering, Bayero University Kano, Nigeria. \\ ${ }^{4}$ Department of Mechatronics Engineering, Faculty of Engineering, Bayero University Kano, Nigeria.
}

ABSTRACT - The present greenhouse effect and its arrays of limitations on energy sources have made Hybrid Electric Vehicles (HEV's) a current research focus due to its reduced amount of fuel usage. The ability to simultaneously deliver power to the wheels from the motor/engine made HEVs to have greater advantages (less fuel consumption and reduced internal combustion engine size without compromising the power output) over the traditional vehicles. Despite its low patronage in the market, there is still hope that its popularity in the global automotive market will rise due to the superior qualities associated with it. In view of the above, this paper presents a brief overview on the developmental trend of the HEV's, right from idea conception till date. It also outlined and discusses the various HEV's architectural configurations, energy source/storage and the motor control strategies.

\section{ARTICLE HISTORY}

Revised: $25^{\text {th }}$ February 2021

Accepted: 26th February 2021

\section{KEYWORDS}

Hybrid Electric Vehicles

Power trains

Energy Storage systems

Battery

\section{INTRODUCTION}

The steady reduction in the worldwide oil reserves along with the set emission guidelines has actually made the demand for vehicles with fuel economy to be very crucial [1]-[3]. The rise in the rate of the world's population increases the demand for vehicles needed for transportation. In countries that are in the developing stage, this rise has become more intense thereby increasing the oil consumption of the vechices [4], [5]. Global warming is an alarming situation that has been the tension in so many parts of the world, leading to the development of strict rules for emission and fuel consumption [6]. The Hybrid Electric Vehicle (HEV) is a motor that use an electric battery, a thermal, and electric driveline coupling device which develops a powertrain and propulsion system

With the transport industries causing about 25-30\% of the world's total gas emission [7], there is need to develop vehicles that can operate using an alternative power. A proposed alternative solution is the battery-powered electric vehicles [8]. This comes with some hitches such as charging time, cost, charging time and driving range. As a result, HEVs proposed to tackle the problems of both the conventional internal combustion vehicles and the battery powered vehicles. In HEVs, the motor is driven by converting the energy from gasoline to mechanical energy with the internal combustion engine. They are environmentally friendly and cheaper as they consume a reduced amount of fuel [9], [10].

\section{HISTORY OF HEV'S}

The first gasoline-electric hybrid vehicle (Volkswagen Beetle, the Mercedes-Benz SS/SSK) was the first front wheeldrive car built in 1898 by an Austrian-German automotive engineer, Ferdinand Porsche. Later he developed a hybrid car that can travel about 40 miles using battery power alone. The car uses an internal combustion engine to power the electric motor in the wheel's hub [6].

Robert Anderson was the first to present the hybrid vehicles in the 19th century [11]. In the year 1900, a Belgian car company called Pieper produced a three and a half horsepower "voiturette" with a small gasoline engine copulated with an electric battery that was mounted under the car seat. The batteries of the car were charged during the cruising stage by the internal combustion engine. Then as the car was accelerating, electric motor boosted the gas engine. After the demise of Pieper, the production of the hybrid vehicle was discontinued. Between 1906 and 1912, another Belgium company (Auto-Mixte) used these patents to manufacture hybrid vehicles.

In 1990, there were about 1681, 1575, and 936 steam, electric and gasoline cars respectively in American car industries. In 1903, the Kriéger Company of Electric Vehicles produced a car that was using gasoline oil to enhance the battery life. Between 1904 and 1920, Henry Ford produced a cheap hybrid car that tackled the problems faced by the conventional gasoline cars (vibration, noise and so on). A patent for a hybrid (petrol-electric) vehicle that reached $25 \mathrm{mph}$ using an electric motor to assist an internal combustion engine was proposed and presented by H. Piper. HEVs were produced by Baker of Cleveland and Woods of Chicago, two famous HEVs manufacturers. The woods claimed that its hybrid vehicle has good fuel regulation and reached a speed of about $35 \mathrm{mph}$. However, they were more expensive and less powerful when compared to the conventional gasoline engine cars. 
In 1970s HEVs emerged once again with the first oil-supply disruption (Arab oil embargo) that led to a worldwide rise in oil price and energy crises. It was announced in 1992 that Toyota would begin the production of non-emitting cheaper vehicles [11]. In 1997, a new path was paved when the first modern HEV was produced in Japan by the Toyota Company (Toyota Prius) with about 18000 yearly sales. In 1999, the Honda Civic with another hybrid car were also sold.The emergence of these vehicles marked the difference in the varieties of vehicle type sold, ranging from the battery powered to gasoline engine cars. By the early 20th century, there were about hundreds to thousands of hybrid electric vehicles.

\section{CONFIGURATION/ARCHITECTURE}

Hybrid Electric Vehicles are driven by an electric motor and an internal combustion engine in a certain configuration (series or parallel). The driven range is provided by the internal combustion engine while the electric motor restores and stores excess energy thereby saving fuel and increasing efficiency. To optimize the HEVs working parameters under any condition, modelling and simulation using intelligent approaches are done during its design and control process.

HEV are mainly classified as series and parallel hybrid. In the series hybrid electric vehicles, energy is apprehended during braking by the electric motor. The output from the internal combustion engine is transformed into electrical output to replace the battery or to power the wheels through an electric motor. In a parallel HEV, power is transferred to the wheel by either the electric motor, or internal combustion engine or the combination of both. This is achieved by joining to the shaft of the wheels the electric motor together with the internal combustion engine. Regenerative braking and storage of excess energy during coasting from the internal combustion engine is achieved by the electric motor. In order to improve the performance efficiency and minimize fuel, a number of other HEV configurations have been developed. The subsection below discusses some of the HEVs architectures. electrically converted

\section{Series HEV}

The series HEV is known as the Range Extended Electric Vehicle (REEV) [12]. In the series HEVs, the output from the internal combustion engine is transformed into an electrical output using a generator. This electrically converted output is either used to power the wheel with the same mechanical principle or used to charge the battery [6]. All of the traction power received is a conversion from electricity in an electric node located at the dc bus [13],[14].

The architecture of the series HEV is shown in Figure 1. The internal combustion engine and electric motor work simultaneously. The generator or battery provides power to the electric motor which in turn further provides traction power [11]. The internal combustion engine's main purpose is to provide power to the motor together with the battery set and, depending on the driving mode (regenerative braking) recharges the battery with the available excess energy [12], [15].

The working principle of the internal combustion engine is either in an off or at its maximum point. It works within a constant level with any excess power transferred to charge the battery at a lessen demand. In a situation of higher power demand from the motor, the battery will provide additional power together with all the power from the generator. The internal combustion engine's power ratings differ with the type of applications of the HEVs. Some examples of Series HEV are Toyota coaster bus, Daimler Hybrid Orion bus, Chevrolet Volt and so on [14], [16], [17].

An advantage of the series HEV is that the internal combustion engine can be decoupled thereby making it, irrespective of the speed flexibility, choose the position of the generator and function. The single transmission source makes the control of the series HEV easier and also without the need for a multi gear transmission. The vehicle is not directly powered by the internal combustion engine as there is no mechanical link or connection with it [14]. The maintenance cost needed in the series HEV is less. However, a bigger battery size is needed for higher power demand [18]. The series HEV helps to solve the main problems in battery electric vehicle (driving range limit). It is achieved by the addition of an internal combustion engine for charging the battery. Hence, it can be termed as an extension of battery electric vehicles. In order to reduce the greenhouse gas effect in the cities, the internal combustion engine is switched off when driving in such area while the power is received only from the battery [17].

One of the drawbacks of the series HEV is the low efficiency associated to it as its power-drive-train is of a simple structure (the internal combustion engine, electric motor and a generator). The cost of the series HEV is high due to the need for larger volume devices for maximum power maintenance during long distance drive. However, a lower rated generator can be used when the distance to cover is short. Six types of Series HEVs operating modes are possible. They are battery (powered by battery), engine (powered by combustion engine/generator), mixed, power share, stationary charging and regenerative braking operating mode [6]. 


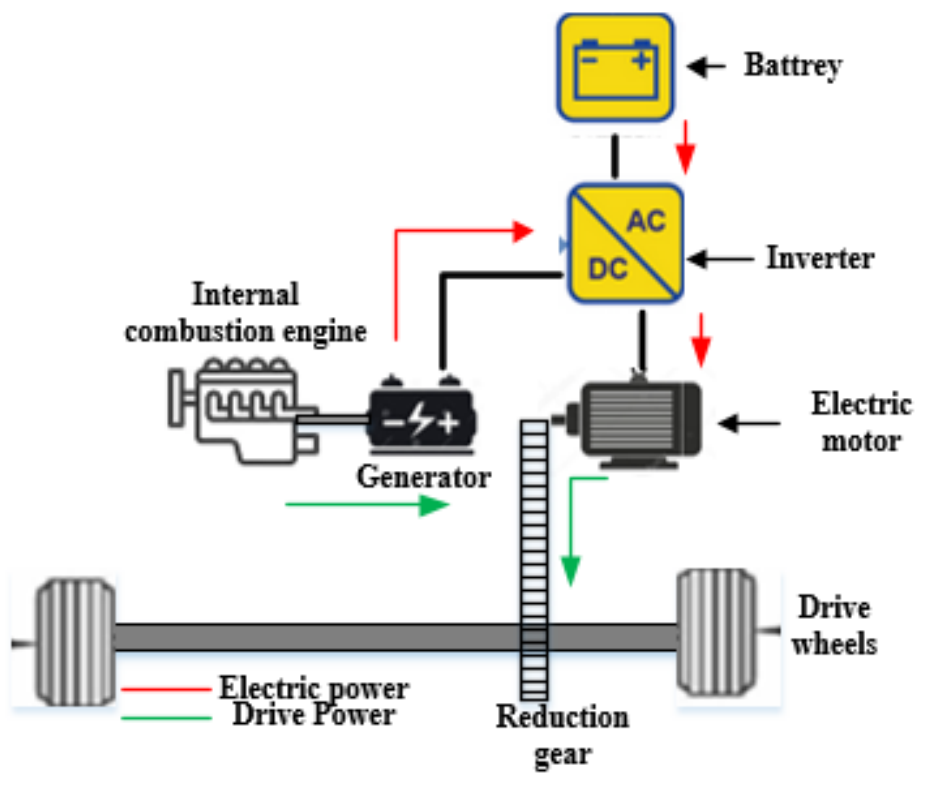

Figure 1. Series HEV [12]

A series parallel HEV architected can be converted into series architecture if there is a link between the internal combustion engine and generator [14].

\section{Parallel HEV}

In the parallel HEV architecture, both the electric motor and internal combustion engine provide parallel traction power to the wheel. This implies that the electric motor and combustion engine can either singly handed or in conjunction with the other provides power as they are coupled to the wheels drive shaft as shown in Figure 2. One or two shafts joined by a pulley, gears, etc., form(s) the mechanical coupling joint where the energy node is located. The battery is charged by either the electric motor during regenerative braking or by the internal combustion engine when it has an available excess power [6], [11], [14], [16]. During regenerative braking, the electric motor serves as the alternator in this configuration [12]. Clutches are needed in the parallel HEV as the combustion engine is mechanically coupled to the transmission hindering it from operating within its optimal range [14]. The greenhouse effect and fuel consumption rate can be reduced by making the internal combustion engine capacity smaller [11].

The mechanical power is simultaneously transferred to the wheels via the drive train from both the internal combustion engine and electric motor. Both of them operate to their optimal point as the power is shared [12]. The decision, on when to switch operation from internal combustion engine to electric motor or when to use both, is decided by a controller. In long distance coverage, the internal combustion engine, in conjunction with the motor, will power the wheels whereas in a short range distance, the electric motor is used solely to provide power [16]. Comparison in terms of efficiency to the series HEV only requires two devices (internal combustion engine and an electric motor)in the parallel HEV. Also, the need for larger sizes is not necessary in the parallel HEV architecture; smaller motors can be utilized to obtain the same performance [14], [12]. Some operation modes for the parallel HEV also include motor, engine, mixed, power split, stationary and regenerative braking operational mode [6].

Examples of parallel HEV are Ford Hybrid SUV, Honda's Insight, Chevrolet Malibu and Lexus SUV [16], [17]. 


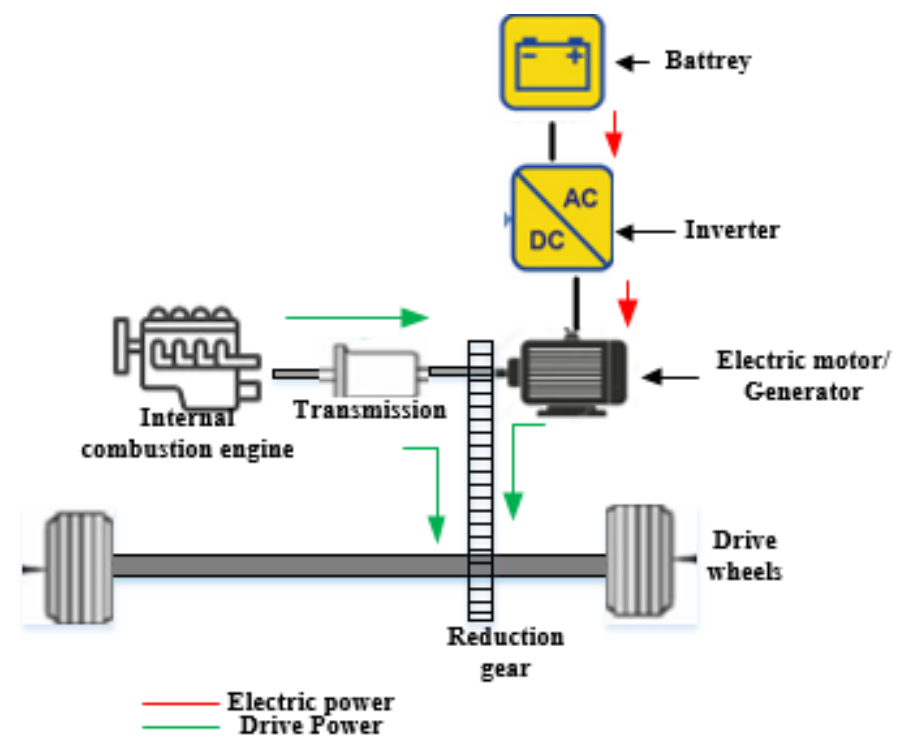

Figure 2. Parallel HEV [12]

A parallel HEV configuration can be achieved form a series parallel by the removal of the generator as shown in the Figure 2.

\section{Series-Parallel HEV}

Series-parallel HEV is also called dual mode HEV, or combined HEV, or Power split HEV [16]. It is a complex architecture that combines both the complexity and advantage of the series and parallel HEVs structures [19]. An additional generator and a mechanical link are incorporated in the parallel and series hybrid respectively [20]. Despite the benefit (Flexibility) derived from the series- parallel hybrid configuration, it comes with an increase in cost and complications. However, some manufacturers of latest HEVs choose to use this configuration [6], [17].

The internal combustion engine mechanical power flows to the wheels via a power split device. Traction power just like in the parallel HEV is received from the mechanically coupled propulsion devices [16]. Figure 3 shows the configuration of this type of HEV with both the alternator and battery providing electric power to the motors based on the driving condition [12]. This configuration has the advantage of running in either series (short distance and slow speed) or parallel mode (for long distance and high speed). An example of a HEV is the Toyota Prius [17].

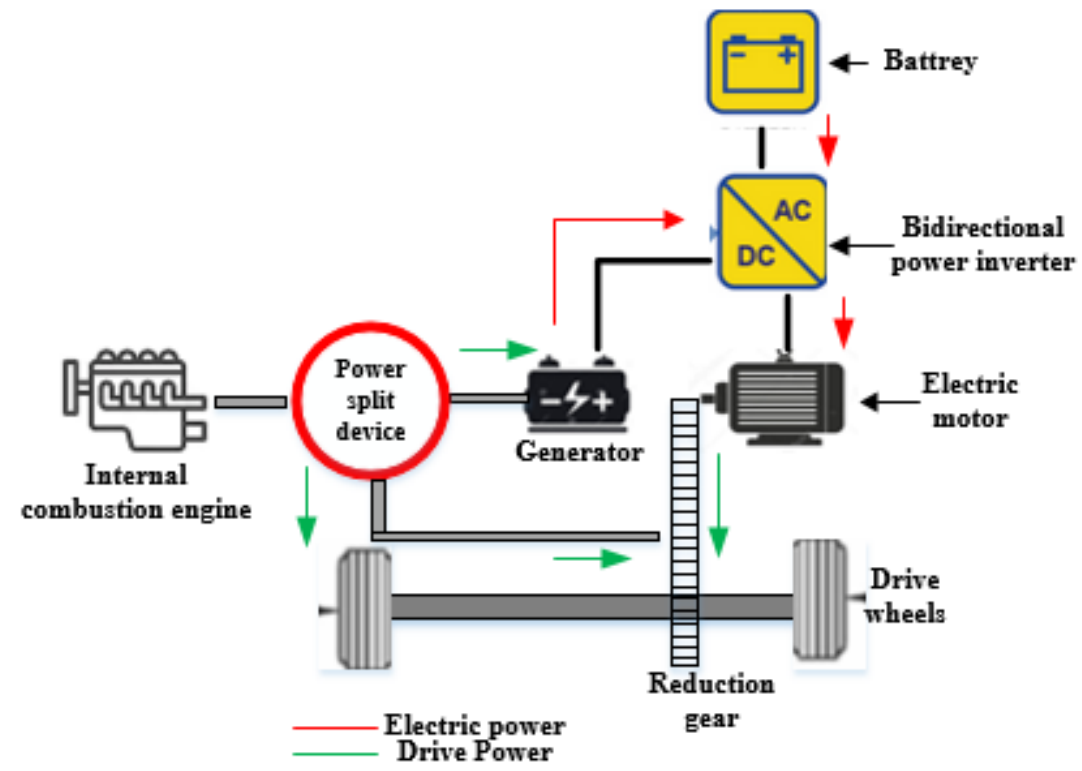

Figure 3. Series-parallel HEV [12]

\section{Complex HEV}

As the name implies, this type of HEV architecture involves a complex configuration. It is similar to the series- parallel architecture having both the motor and generator as electrical machines. The motor power flow in the complex HEV is bidirectional whereas the series-parallel generator power flow is unidirectional [21]. Unlike in the series-parallel HEV, 
three propulsion power operating mode is possible in the complex HEV due to its bidirectional power flow capability. In series-parallel HEV, high cost and complexity are the major problems in the complex HEV [6], [22].

\section{Plug-in Hybrid Vehicles (PHEV)}

Another means for battery charging through grid outlet is the plug-in hybrid vehicles. A vehicle to Grid or Grid to Vehicle technology is formed when power exchange via grid outlet is carried out between HEVs and power grid [12]. Plug-in hybrid vehicles have become the latest development in the automobile industry due to its operational mode. It works similar to the HEVs operation coupled with a new featured known as the "all electric range" [6]. The Plug-in Hybrid vehicles has a motor located at the top of the configuration, and uses an electric power train as the primary source in place of the mechanical one employed in the conventional HEV.

\section{Fuel Cell Vehicles and Battery Electric Vehicles}

Fuel cell vehicle is another series-type of HEV which can be made with super-capacitors or batteries [23]. In FCV, an electrical hydrogen generator serves as the fuel cell [24]. The power provided to the wheel or that which is reserved in the battery is produced as electricity by the on-board fuel cell [6], [14].

In the battery electric vehicles, zero greenhouse emission is achieved as they are solely powered by batteries or electricity alone. BEV architecture can be obtained when only the electric motor in the series-parallel architecture is left. This type of architecture is rarely used due to its high cost and coverage distance range coupled with the time taken in refuelling. However, new BEV architectures with some energy sources also linked to the dc bus have been proposed to tackle these problems [14].

\section{Energy Sources}

HEVs use batteries, fuel cells, ultra-capacitor and flywheel as sources of energy depending on the configuration of the HEV's power flow. Main energy and rechargeable energy storage system are the two energy sources that are simultaneously used by most HEVs [16]. For accurate selection of these systems, their power and energy densities are considered. For a dependable steady power supply, the Main Energy Storage is used due to its high energy storage capability. However, for regenerative breaking and a transient power, the rechargeable energy storage system is utilized due to its reversibility and high power capability [25]. Battery and fuel cell have high energy density; Figure 4 shows some of the energy sources and their respective ranges. Based on this, they can be used for Main Energy Storage while flywheels and ultra-capacitors due to their low energy density can be used for rechargeable energy storage system.

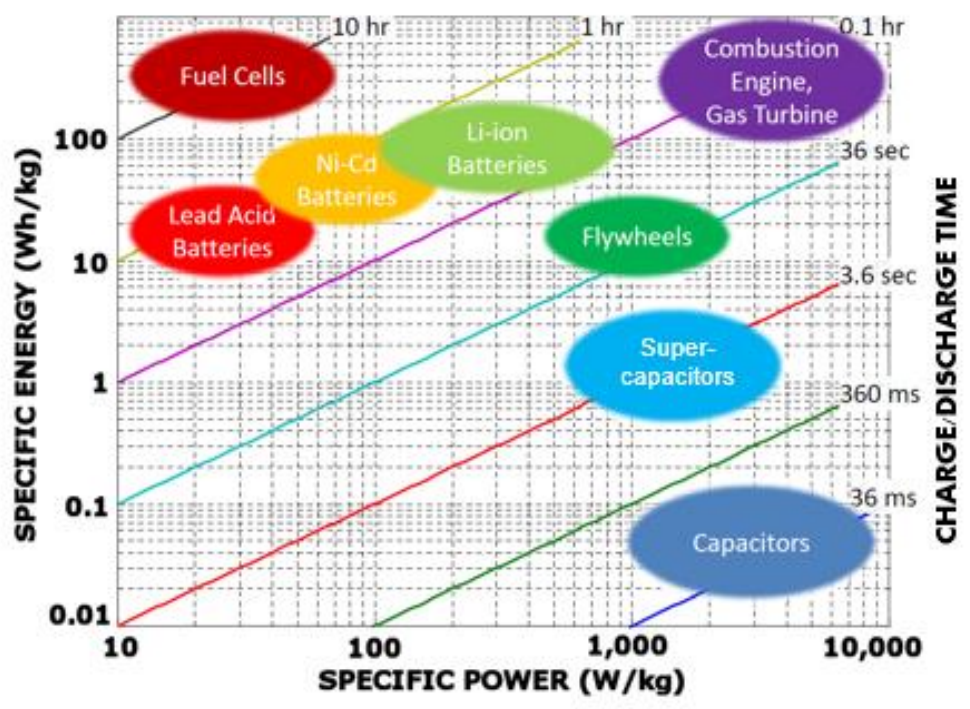

Figure 4. Energy/Power -Storage devices [25] 


\section{Battery}

Battery is one of the popularly sold and available storage devices [26]. It converts chemical energy into electrical energy by using one or more of its electrochemical cells. These batteries are either non rechargeable (primary) or rechargeable (secondary). The rechargeable battery is mainly used for HEV application. The HEVs uses batteries that have high capacity and handle large power different from the ones used by our electronic devices (phones and PC). The different types that are readily available are lead acid battery, Nickel Zinc (NiZn), Nickel Metal Hydride (NiMH), Nickel Cadmium (NiCa) battery and so on.

The lead acid battery which is the popular and cheapest is made from lead peroxide and soft sponge lead in the positive and negative plate respectively. To produce electricity, a sulphuric acid is used as the electrolyte with the plates dipped into it [27]. A leading edge to the lead acid battery is its high efficiency, low maintenance and discharge rate with a life cycle of 300e500. However, they are large in size and easily get heated when charging [28]. Thus, they are mostly used in small size EVs. Nickle metal hydride batteries have a higher (twice) energy density level, longer life and they are environment-friendly when compared to the lead acid batteries [29], [30]. However, the long period of charging with the generation of heat at high temperature is one of its major drawbacks. The positive and the negative leads are made from nickel hydroxide and alloy nickel, vanadium and titanium metals, and the electrolyte is an alkaline solution.

Another high power density rechargeable environment-friendly substitute to NiMH battery is the Nickel zinc battery [31], [32]. Still, these batteries are rarely used in EV applications due to their low life cycles. The Nickel cadmium batteries have a high life cycle and energy density. The electrodes are made from metallic cadmium and nickel hydroxide . These batteries are rechargeable and can be discharged fully. A major drawback associated to these batteries is their high cost and environmental hazard. The high energy and power densities, life, and performance of the lithium ion batteries have made them to be commonly used in EVs. An oxidized cobalt and carbon material is used in the positive and the negative electrodes, respectively, while salt serves as the electrolyte. In Chevrolet, Tesla Roadster and Nissan, lithium ion is used for energy storage [33], [34], [35]. However, these batteries are costly [36].

\section{Fuel cell}

Fuel cell transforms fuel into an electricity using an electrochemical device through a chemical reaction with hydrogen as the most commonly used fuel. Air and fuel serving as the input are converted into water and electricity respectively [37], [38]. Similar to the characteristics of a battery, the fuel cell under certain loading situations works continuously like an internal combustion engine.

The first fuel cell was presented in 1839 by Sir William Robert Grove. Francis Bacon later in 1950 proposed and presented the first $5 \mathrm{~kW}$ fuel cell. Later on in the late 1950's, the international fuel cells developed a 12kW fuel cell for the NASA space craft. Before now, fuel cells had been a commonly used power source for both residual and industrial sectors.

Recently, fuel cell has been the attraction of automobile industries in the manufacturing of HEVs. Figure 5 shows the diagram of a fuel cell [39]. It is made up of an anode and cathode electrode and an electrolyte.

Using the principle of electrochemical process, as the hydrogen fuel is supplied through the anode, the bonded positive and negative charged ions are separated by the catalyst. Electric energy is produced at the output of the fuel cell when both hydrogen and oxygen are supplied into the cell in the presence of an electrolyte [40]. This process is described by equation 1 below.

$$
2 \mathrm{H}_{2}(g)+\mathrm{O}_{2}(g) \rightarrow 2 \mathrm{H}_{2} \mathrm{O}+\text { energy }
$$

The reactions taken place at the cathode and anode are described by equations 2 and 3

Cathode:

$$
\begin{aligned}
& \mathrm{H}_{2} \rightarrow 2 \mathrm{H}^{+}+2 e^{-} \\
& \frac{1}{2 \mathrm{O}_{2}}+2 \mathrm{H}^{+}+2 e^{-} \rightarrow \mathrm{H}_{2} \mathrm{O}
\end{aligned} \quad \text { Anode: }
$$




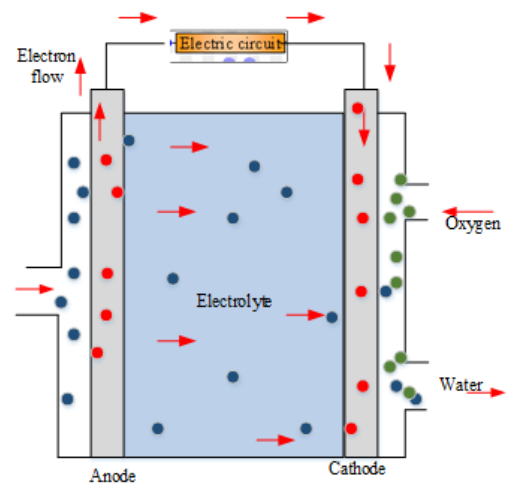

Figure 5. Fuel cell [16]

Ideally, the chemical reaction of $\mathrm{O} 2$ and $\mathrm{H} 2$ should produce $1.23 \mathrm{~V}$. However, the produced voltage is normally less than the value due to the activation and ohmic loss [41], [44]. The fuel can be classified into the following depending on the type of electrolyte. [42], [43]:

- Alkaline fuel cell

- Phosphoric acid fuel cell

- $\quad$ Proton exchange membrane fuel cell

- $\quad$ Solid oxide fuel cell

- Molten carbonate fuel cell

Presently, the Proton Exchange Membrane Fuel Cell (PEMFC) due to its size, power density, and operating temperature is popularly used in the automobile industries [44], [45].

\section{Ultra-capacitor}

Ultra-capacitor which is also referred to as super or electrochemical capacitor has high energy $(374.4 \mathrm{KJ} / \mathrm{m} 3)$ and power $(106 \mathrm{~W} / \mathrm{m} 3)$ density as well as capacitors with a range measured in Farads (F) [46], [47]. When compared to the traditional capacitors, ultra-capacitor has a larger surface area, long life, charges and discharges faster. The dielectric material used in ultra-capacitor is made from activated carbon. Ultra-capacitors can be categorized into three classes depending on the electrode materials, as shown in the figure [48], [49]:

- $\quad$ Electrostatic double layer capacitors (carbon electrode)

- $\quad$ Pseudocapacitors (metal oxide polymer)

- Hybrid capacitors

\section{Flywheel energy storage}

Flywheel is a tool that stores energy in the form of mechanical energy. It operates in an energy storage and discharge method, storing the energy during the application of torque [50]. Flywheel energy storage consists of a rotor bearing, power interface and a rotating flywheel, which are mostly used for grid energy storage, space craft, UPS and EVs [51].

Based on its operational speed, they are classified into two: a low (6000rpm) and high (50000rpm) speed flywheel. The former consist of an advanced composite material rotor and low friction bearing while the latter is made from steel material rotor and the traditional bearings. The power interface is made up of a generator (high speed permanent magnet motor), a power converter (single or double AC to AD) and a controller (for controlling the power system). A major advantage of the flywheel energy storage system is the less recharging and maintenance time, and high life cycle. However, the issue of safety is one of the main problems in EVs' flywheel.

\section{Regenerative braking}

Regenerative braking or kinetic energy recovery system is the process of transferring electric power to an energy storage device using kinetic energy from a moving vehicle during braking [52]. The energy is captured and stored by four distinct methods [53]:

1. By directly storing the generated energy in the energy storage system,

2. Storing the energy in a canister using hydraulic motors,

3. Storing the energy in a rotary form in a flywheel energy storage system, and

4. Storing the energy in the form of a gravitational form in a spring.

The problem of fuel emission is reduced by regenerative braking. However, the amount of energy needed to slow down or bring the vehicle to stop cannot be generated by the regenerative braking system alone. As a result, it works in 
conjunction with the friction brake. The generator, battery, ultra-capacitor and the power drive capacity determine the efficiency of the regenerative braking [54].

\section{MOTOR CONTROL MECHANISM}

An Electric Vehicle (EV) is driven by a motor, which is supplied by the battery via a controlled power circuit. Aside from circuit for control of the motor, there is fairly a lot of auxiliary control for auto electronics [55], [56]. The control strategies are implemented in the microprocessor, such as Digital Signal Processor (DSP) [57]. Control of electrical vehicle is essentially the control of motor. With different electric motors, it is necessary to use various control techniques. It is noticed that typically Pulse Width Modulation (PWM) control is used for DC motor, while Variable Voltage Variable Frequency (VVVF), Field Oriented Control (FOC) and Direct Torque Control (DTO) are employed for induction motor [57]-[60]. Moreover, some traditional control algorithms, such as PID (Proportional Integral Derivative), cannot satisfy the requirements of EV control. Several modern-day high-performance control technologies, such as adaptive control, fuzzy control, artificial neural network and expert system are being used in EV controllers [59], [61], [62].

\section{CONCLUSION}

This paper has presented an overview of Hybrid Electric Vehicles, by focusing on history, architecture,energy sources and control strategies. With the present greenhouse effect and limitations sets on energy sources, Hybrid Electric Vehicles have become a popular topic of research due to its low emission rate and less fuel usage. HEV's offers tremendous advantages but still a lot needs to be done in both it technological aspect and marketing strategies. The combine power of it twin engines ( electric and gasoline) is less than that of a single gasoline engine, hence limiting it usage to within the cities and metropolitan. There are reported cases of electrocution due to high voltage in the batteries. Therefore, the production companies need to improve the engine power as well as provide proper insulation and protective measures in all electrical wirings and devices within the vehicle. The high initial and maintenance cost of HEV's makes it unaffordable and not easy to maintain. Hence, concerned stakeholders and governments needs to draw out modalities ranging from credit loans, incentives and tax waivers that will encourage people to patronize it.

Despite its low market patronage, there is still hope that its popularity in the market will rise due to the superior qualities associated with it.

Hence, this article will serve as a stepping stone for both old and new researchers with keen interest in the area of Hybrid Electric Vehicle.

\section{REFERENCES}

[1] A. Brahma, Y. Guezennec, G. Rizzoni. Dynamic Optimization of Mechanical/Electrical Power Flow in Parallel Hybrid Electric Vehicles. In Proceedings of the 5th international symposium in advanced vehicle control, Ann Arbor, (2000).

[2] N.J. Schouten, M.A. Salman, N. AKheir.: Energy management strategies for parallel hybrid vehicles using fuzzy logic. Control Engineering Practice 11(2), 171-177 (2013).

[3] S. Delprat, J. Lauber, T. M. Guerra, J. Rimaux.: Control of a parallel hybrid powertrain: optimal control, IEEE Trans Vehic Tech 53(3), 872 - 881 (2004).

[4] H. Aouzellag, K. Ghedamsi, D. Aouzellag.: Energy management and fault tolerant control strategies for fuel cell/ultracapacitor hy-brid electric vehicles to enhance autonomy, efficiency and life time of the fuel cell system. Int J Hydrogen Energy 40(22), 7204-7213 (2015).

[5] A. R.Gopal, W. Y, Park, M. Witt, A. Phadke.: Hybrid- and battery-electric vehicles offer low-cost climate benefits in China. Transportation Research Part D: Transport and Environment 62, 362-371 (2018).

[6] C.C. Chan.: The State of the Art of Electric, Hybrid, and Fuel Cell Vehicles. In Proceedings of the IEEE 95 (4), $704-718$ (2007).

[7] F. Badin, J. Scordia, R. Trigui, E. Vinot, B. Jeanneret.: Hybrid electric vehicles energy consumption decrease according to drive train architecture, energy management and vehicle use. In IET - The Institution of Engineering and Technology Hybrid Vehicle Conference, Coventry, UK (2007).

[8] B. Richardson, David.: Electric vehicles and the electric grid: A review of modeling approaches, Impacts, and renewable energy in-tegration. Renew Sustain Energy Rev 19, 247-254 (2013).

[9] P. Leduc, B. Dubar, A. Ranini and G. Monnier.: Downsizing of Gasoline Engine: an Efficient Way to Reduce CO2 Emissions. Oil \& Gas Science and Technology - Rev. IFP 58 115-127 (2003).

[10] T. Takaishi, A. Numata, R. Nakano , K. Sakaguchi.: Approach to High Efficiency Diesel and Gas Engines. Mitsubishi Heavy Industries, Ltd Technical Review 45(1) (2008).

[11] N. Penina, V. Y. Turygin, V Racek.: Comparative analysis of different types of hybrid electric vehicles. In 13th Mechatronika, Trencianske Teplice, Slovakia (2010).

[12] A. Zia.: A comprehensive overview on the architecture of Hybrid Electric Vehicles (HEV). in 2016 19th International MultiTopic Conference (INMIC), Islamabad, Pakistan (2016).

[13] C.K. Wai, Y.Y. Rong, S. Morris.: Simulation of a distance estimator for battery electric vehicle. Alexandria Engineering Journal 54(3), 359-371 (2015).

[14] C.C. Chan, A. Bouscayro, K. Chen.: Electric, Hybrid, and Fuel-Cell Vehicles: Architectures and Modeling. IEEE Transactions 
on Vehicular Technology 59(2), 589 - 598 (2009).

[15] Lucena, S. E. de.: A Survey on Electric and Hybrid Electric Vehicle Technology. In Electric Vehicles - The Benefits and Barriers, pp. 1-18. Unesp - São Paulo State University, Brazil (2011).

[16] J. K. Reddy., S. Natarajan.: Energy sources and multi-input DC-DC converters used in hybrid electric vehicle applications A review. Int J Hydrogen Energy 43, 17387-174081 (2018).

[17] Edward W C.: Review on the Configurations of Hybrid Electric Vehicles. In 3rd International Conference on Power Electronics Systems and Applications (PESA), Hong Kong, China (2009).

[18] A.M. Lulhe, T.N. Date.: A technology review paper for drives used in electrical vehicle (EV) \& hybrid electrical vehicles (HEV). In International Conference on Control, Instrumentation, Communication and Computational Technologies (ICCICCT). Kumara-coil, India. (2016).

[19] B. Mashadi, S.A.M. Emadi.: Dual-Mode Power-Split Transmission for Hybrid Electric Vehicles. IEEE Trans on Vehicular Technology 59(7) 3223 - 3232 (2010).

[20] J. K. Kim, E. S. Yim, C. H. Jeon, C. S. Jung, B. H. Han.: Cold performance of various biodiesel fuel blends at low temperature. International Journal of Automotive Technology 13(2) 293-300 (2012).

[21] N. Briguglio, L. Andaloro, M. Ferraro, V. Antonucci.: Fuel Cell Hybrid Electric Vehicles. In Electric Vehicles - The Benefits and Barriers, InTech (2011).

[22] T. Alagarsamy, B. Moulik.: A Review on Optimal Design of Hybrid Electric Vehicles and Electric Vehicles. In 3rd International Conference for Convergence in Technology (I2CT), Pune, India (2018).

[23] J. Lai, D.J. Nelson.: Energy Management Power Converters in Hybrid Electric and Fuel Cell Vehicles. Proceedings of the IEEE 95(4) 766 - 777 (2007).

[24] D. Hissel, D. Candusso, F. Harel.: Fuzzy-Clustering Durability Diagnosis of Polymer Electrolyte Fuel Cells Dedicated to Transportation Applications. IEEE Transactions on Vehicular Technology 56(5) 2414 - 2420 (2007).

[25] M. Al Sakka, J. Van Mierlo, H. Gualous.: DC/DC Converters for Electric Vehicles. In Electric Vehicles - Modelling and Simulations, pp. 310-311(2011).

[26] F. Díaz-González, A. Sumpera, O. Gomis-Bellmunta, R. Villafáfila-Robles.: A review of energy storage technologies for wind power applications. Renewable and Sustainable Energy Reviews 16(4) 2154-2171 (2012).

[27] L. Zhang, J. Jung, J. Zhang.: Lead-acid battery technologies: fundamentals, materials, and applications., CRC Press (2015).

[28] V. Esfahanian, A.B. Ansari, F. Torabi.: Simulation of lead-acid battery using model order reduction. Journal of Power Sources 279, 294-305 (2015).

[29] J. Kang, F. Yan, P. Zhang, C. Du.: Comparison of comprehensive properties of Ni-MH (nickel-metal hydride) and Li-ion (lithium-ion) batteries in terms of energy efficiency. Energy 70(1) 618-625 (2014).

[30] H. Yang, Y. Qiu, X. Guo.: Prediction of state-of-health for nickel-metal hydride batteries by a curve model based on chargedischarge tests. Energies 8 12474-12487 (2015).

[31] S. Yao, P. Liao, M. Xiao, J. Cheng, W. Cai.: Study on electrode potential of zinc nickel single-flow battery during charge. Energies 10(8) 1101 (2017)

[32] S.O. Amrouche, D. Rekioua, T. Rekioua, S. Bacha.: Overview of energy storage in renewable energy systems. international Journal of Hydrogen Energy 41(45), 20914-27 (2016).

[33] G. Ren, G. Ma, N. Cong.: Review of electrical energy storage system for vehicular applications. Renewable and Sustainable Energy Review 41, 225-236 (2015).

[34] S. Juan, B. Hans, E.Boel, E. Sandra, F. Senad, W. Rafael.: Electrical motor drivelines in commercial all. IEEE Transaction on Vehicular Technology 61, 12 (2012).

[35] M.M. Hackeray, C. Wolverton, E.D. Isaacs.: Electrical energy storage for transportationdapproaching the limits of, and going beyond, lithiumion batteries. Energy and Environmenrtal Science5, 7854 (2012).

[36] L. Lu, X. Han, J. Li, J. Hua, M. Ouyang.: A review on the key issues for lithiumion battery management in electric vehicles. Journal of Power Sources 226, 272-288 (2013).

[37] D. Rekioua, S. Bensmail, N. Bettar. Development of hybrid photovoltaic-fuel cell system for stand-alone application. International Journal of Hydrogen Energy. 39(3), 1604-1611 (2014).

[38] R. O'hayre, S.W. Cha, F.B. Prinz, W. Colella. Fuel cell fundamentals. John Wiley \& Sons, (2016).

[39] A. Saadi, M. Becherif, D. Hissel, H.S. Ramadan. Dynamic modeling and experimental analysis of PEMFCs: a comparative study. International Journal of Hydrogen Energy, 42(2), 1544-1557, (2017).

[40] A. Harrag, H. Bahri. Novel neural network IC-based variable step size fuel cell MPPT controller: performance, efficiency and lifetime improvement. International journal of Hydrogen energy, 42(5), 3549-3563. (2017).

[41] A.S. Samosir, A. H. M. Yatim. Dynamic evolution control of bidirectional DC - DC converter for interfacing ultracapacitor energy storage to fuel cell electric vehicle. 57, 3468-3473,(2010).

[42] S. Mekhilef, R. Saidur, A. Safari. Comparative study of different fuel cell technologies. Renewable and Sustainable Energy Review. 16, 981-989.(2012).

[43] O.Z Sharaf, M.F. Orhan. An overview of fuel cell technology: fundamentals and applications. Renewable and Sustainable Energy Review. 32, 810-853. (2014)

[44] D. Gao, Z. Jin, J. Zhang, J. Li, M. Ouyang. Development and performance analysis of a hybrid fuel cell/battery bus with an axle integrated electric motor drive system. International journal of Hydrogen Energy. 4(12),1161-1169. (2016).

[45] K.J. Reddy, N. Sudhakar. High voltage gain interleaved boost converter with neural network based MPPT controller for fuel cell based electric vehicle applications. IEEE Access. 6, 3899-3908. (2018)

[46] A. Ultracapacitor technologies and application in hybrid and electric vehicles. International Journal of Energy Reserve. 34(2), 133-151. (2010).

[47] S. Faraji, F. N. Ani. The development supercapacitor from activated carbon by electroless platingda review. Renewable and Sustainable Energy Review. 42, 823-834. (2015).

[48] L. Dong, C. Xu, Y. Li, Z. H. Huang, F. Kang, Q. H. Yang. Flexible electrodes and supercapacitors for wearable energy storage: a review by category. J Mater Chem A, 4(13), 4659-4685. (2016).

[49] A. Gonzlez, E. Goikolea, J. A. Barrena, R. Mysyk R. Review on supercapacitors: technologies and materials. Renewable and sustainable Energy Review, 58, 1189-1206, (2016). 
[50] G. S. M. Mousav, F. Faraji, A. Majazi, K. A. Al-Haddad. comprehensive review of flywheel energy storage system technology. Renewable and Sustainable Energy Review, 67, 477-490, (2017).

[51] A. A. K. Arani, H. Karami, G. B. Gharehpetian, M. S. A. Review of Flywheel Energy Storage Systems structures and applications in power systems and microgrids. Renewable and Sustainable Energy Review, 69 9-18, (2017).

[52] L. Li, Y. Zhang, C. Yang, B. Yan,C. M. Martinez. Model predictive control-based efficient energy recovery control strategy for regenerative braking system of hybrid electric bus. Energy Conversion and Management, 111. 299-314. (2016).

[53] B. R. G. Wang, C. Q. Ying, S. H.Wen. Experimental research on regenerative braking of wheel-hub motor. Advanced materials research. Manufacturing Science and Technology, 1879-1883, (2012).

[54] X. Nian, F. Peng, H. Zhang. Regenerative braking system of electric vehicle driven by brushless DC motor. IEEE Transanction in Industrial Electronics, 61, 5798-5808. (2014).

[55] M. Tayarani-N., X. Yao and H. Xu. Meta-Heuristic Algorithms in Car Engine Design: A Literature Survey. In IEEE Transactions on Evolutionary Computation. 19(5), 609-629, (2015).

[56] K. Sharma, A. Agrawal, S. Bandopadhaya and S. Roy .Fuzzy Logic Based Multi Motor Speed Control of Electric Vehicle. In IEEE 5th International Conference for Convergence in Technology (I2CT), Bombay, India, 1-5, (2019)

[57] Q. Liu, Y. Zhong, Z. Zhou. Research of drive control system in electric vehicle based on DSP. In 7th Int. Conf. Signal Processing, Beijing, China. 539 - 542. (2004)

[58] S. Stockar, M. Canova, Y. Guezennec, A. Della Torre, G. Montenegro, A. Onorati. Modeling wave action effects in internal combustion engine air path systems: comparison of numerical and system dynamics approaches. International Journal of Engine Research. 14(4), 391-408, (2013)

[59] S. Poorani, K. Kumar, S. Renganarayanan. Intelligent controller design for electric vehicle. In Proc. 57th IEEE Semiannual Vehicular Technology Conf., Jeju, Korea, 2447 - 2450, (2003)

[60] V.T. Liu. Design of Power System Control in Hybrid Electric Vehicle. World Electric Vehicle Journal. 4(1):4954. (2010) https://doi.org/10.3390/wevj4010049

[61] A.H. Ahangarnejad, A. Radmehr, M. Ahmadian. A review of vehicle active safety control methods: From antilock brakes to semiautonomy. Journal of Vibration and Control. August (2020). doi:10.1177/1077546320948656

[62] H.A. Yavasoglu, Y.E. Tetik, H.G. Ozcan, "Neural network-based energy management of multi-source (battery/UC/FC) powered electric vehicle," International Journal of Energy Research, 2020, 44(15): pp. 1241612429. https://doi.org/10.1002/er.5429 